\title{
Akademik Personel Performans Değerlendirmesinde Bir Karar Destek Sistemi Önerisi
}

\author{
Araştırma Makalesi/Research Article
}

\author{
Emrah Aydemir ${ }^{1}$ \\ ${ }^{1}$ Bilgisayar Mühendisliği, Kırşehir Ahi Evran Üniversitesi, Kırșehir, Türkiye (Bölüm, Üniversite, Şehir, Ülke) \\ emrah.aydemir@ahievran.edu.tr \\ (Geliş/Received:17.11.2018; Kabul/Accepted:01.04.2019) \\ DOI: $10.17671 /$ gazibtd.484509
}

\begin{abstract}
$\ddot{O}_{z e t}$ - Üniversiteler eğitim düzeyinin son kademesi olup, bilim ve teknoloji alanlarındaki faaliyetleri ile özgün ve lider bir üniversite olmayı amaçlarlar. Elbette ki bu amaca ulaşmanın en büyük gerekliliği, bilimsel yetkinliğe sahip akademik personel sayısıdır. Bir akademik personelin yetkinliği ise farklı ölçüt sistemleri ile değerlendirilmektedir. Üniversitelere atanma ve yükseltme, doçentlik ve akademik teşvik gibi ölçüt sistemleri akademik personelin akademik geçmişine bakarak; yayınlarını, makalelerini, bildirilerini, kitap ve kitap bölümlerini, verdiği derslerini, lisans ve lisansüstü tez danışmanlıklarını, ödüllerini, üyeliklerini, idari görevlerini, projelerini, araştırmalarını, atıflarını, sergilerini vb. birçok çalışmasını içermektedir. Fakat buradaki ölçütler ve ölçütlerin değerlendirilme puanları üniversiteden üniversiteye farklılık göstermektedir. Ölçütler genel olarak akademik başarı ve yayın kriterlerinden oluşmakta iken personelin daha önce post-doktora yapıp yapmadığını veya daha öncesinde kaç yıllık bir akademik geçmişe sahip olduğunu dikkate almamaktadır. Bu çalışmada ise üniversitelerin mevcut atama ve yükseltme yönergeleri incelenerek tüm ölçütler çıkartılmış ve bu ölçütlerin değerlendirilmesi için oluşturulan karar destek sistemi önerisi (KDS) sunulmuştur. KDS aracılığıyla her üniversite kendi ölçüt sistemine göre parametre değerlerini girip puanlamaları görerek; üniversite, fakülte veya bölüm bazında sıralamalar yapabilecektir. Aynı zamanda her öğretim elemanı kendisinin her bir alandaki puanını diğer bölüm veya kişilere göre durumunu analiz edebilecektir. Tüm bunların yanı sıra Türkiye'deki tüm yükseköğretim kurumları da diğer kurumlar içerisinde kendi pozisyonunu değerlendirme imkânı olacaktır. Ayrıca akademik personelin performans ölçümüne etki edecek tüm verilerin toplanması ile hem değerlendirmenin eksik yanları kapatılacak olup hem de tüm akademik personelin özgeçmişlerinin yayınlanması sağlanacaktır.
\end{abstract}

Anahtar Kelimeler — akademik personel atama yükseltme, karar destek sistemi, üniversite

\section{A Decision Support System Suggestion in Academic Personnel Performance Evaluation}

\begin{abstract}
Universities are the last level of education and aim to be a unique and leading university with their activities in science and technology. Of course, the biggest necessity of achieving this objective is the number of academic staffs with scientific competence. The competence of an academic staff is evaluated by different criteria systems. These criteria systems are based on the academic background of the academic staff; publications, articles, conference presentations, book and book chapters, lessons, undergraduate and graduate thesis advisors, awards, membership, administrative tasks, projects, research, references, exhibitions and so on. However, the criteria and assessment scores are different from university to university. The criteria generally consist of academic achievement and publication criteria, but do not consider whether the staff had a post-doctoral degree before, or how many years of academic history they had before. In this study, all criteria were removed by examining the existing Criteria such as appointment and promotion to universities, associate professorships and academic incentives are based on the academic background of academic staff; publications, articles, papers, book and book chapters, lectures, undergraduate and graduate thesis advisors, awards, membership, administrative tasks, projects, research, references, exhibitions and so on. It contains many studies. However, the criteria and criteria for evaluating these criteria vary from university to university. The criteria generally consist of academic achievement and publication criteria, but do not consider whether the staff had
\end{abstract}


previously had a post-doc or a few academic years before. In this study, all criteria were determined by examining the current assignment and upgrade guidelines of universities and a decision support system proposal (DDS) was prepared to evaluate these criteria. Each university through the DSS by entering the parameter values according to their own criteria system and seeing the scores; will be able to make rankings on the basis of university, faculty or department. At the same time, each instructor will be able to analyze his / her own score in each field by other departments or individuals. All this as well as all higher education institutions in Turkey will assess the possibility of their positions within other institutions. In addition, by collecting all data that will affect the performance measurement of academic staff, the shortcomings of the evaluation will be closed and the CVs of all academic staff will be published.

Keywords - academic staff assignment upgrade, decision support system, university

\section{GIRISS (INTRODUCTION)}

Eğitim düzeyinin son kademelerini oluşturan üniversiteler bilim ve teknoloji alanlarında ileri düzeyde araştırma, eğitim, öğretim, üretim, yayın ve danışmanlık yapmayı misyon olarak belirlerken, bu misyona uygun bilim ve teknolojide öncü, eğitimde özgün ve lider üniversite olmayı amaçlarlar. Fakat tüm bunları gerçekleştirmek için öncelikle bilimsel yetkinliği sağlamış akademik personele sahip olmak kaçınılmaz bir ihtiyaçtır. Öğrenme ve bilime duyulan tutku, akademisyenleri araştırmaya yönelten en önemli etmenlerdendir. Akademisyenler hiç büyümeyen öğrenciler olarak nitelendirilebilir. Bu duruma mesleki ilerlemenin zorladığı gereksinimler ya da kadroya atanma, akademik olarak yükselme ve saygınlık gibi nedenlerle bilimsel araştırma yapmak neden olur. [1]. Bu bağlamda üniversitelerdeki karar vericiler üniversitelerin niteliğini yükseltmek için niceliksel hedefler koyarlar. Elbette ki niceliksel artışın her zaman ilgili bilim alanına anlamlı bir katkı sunduğu söylenemez [2]. Bu nedenle üniversitelerin bu konuya yaklaşımlarında farklılıklar görülmektedir.

Üniversitelerde akademik personel olmak veya yükselmek ihtiyaçlar sonucu yasada belirlenen koşulların yanı sıra kurumun kadroya özel ek koşullar eklediği kadro ilanı ile başlayıp; farklı birim, kişi ve kurulların katıldı ̆̆ bir süreç sonucu rektör tarafindan atanma ile sonuçlanır [3]. Bir akademik personelin yetkinliği farklı ölçüt sistemleri ile değerlendirilmektedir. Akademik personelin yayınları, makaleleri, bildirileri, kitap ve kitap bölümleri, verdiği dersleri, lisans ve lisansüstü tez danışmanlıkları, ödülleri, üyelikleri, idari görevleri, projeleri, araştırmaları, atıfları, sergileri vb. birçok çalışması bu ölçüt sistemleri içerisinde yer almaktadır. Üniversitelerde öğretim, araştırma ve yayın kalitesinin yükseltilmesi için de bu tür ölçütler kullanılmaktadır [4]. Fakat buradaki hem ölçütler hem de ölçütlerin değerlendirilme puanları üniversiteden üniversiteye farklılık göstermektedir. Ölçütler genel olarak akademik başarı ve yayın kriterlerinden oluşmakta iken personelin daha önce post-doktora yapıp yapmadığını veya daha öncesinde kaç yıllık bir akademik geçmişe sahip olduğunu dikkate almamaktadır [5]. Akademisyenlerin zaten performanslarının belirli aralıklarla değerlendirilebileceği bir performans değerlendirme sistemine olumlu baktıkları bilinmektedir [6].

\section{AMAÇ (AIM)}

Kuşkusuz bir ülkenin bilimsel ve teknolojik anlamda gelişmişliğini gösteren en önemli ölçütler arasında ürettiği bilimsel yayınların sayısı ve kalitesi yer almaktadır [7]. Üniversitelerin kuruluş amaçları arasında toplumun nitelikli insan gücü gereksiniminin karşılanması, toplumun bilimsel üretkenliğini sağlama ve sürdürme, bilgi ve teknoloji üretme ve ulaşılan bilimsel verilerin toplumla paylaşılması yer alır [8]. $\mathrm{Bu}$ sebeple yüksekögretim kurumları akademik personellerin yaptığ 1 çalışmalar üzerinden birçok farklı sıralama sistemlerinde değerlendirmeye tabi tutulurlar. Ayrıca bu kurumlar da kendi personelinin performansını değerlendirmek için belirli periyodlarla akademik faaliyetleri analiz eder. Öğretim üyeleri akademik olarak yükselme ve yeniden atanmada yapmış olduğu faaliyetler ile atanmak istediği üniversitenin puan şartını sağlaması gerekir [9]. Tüm bunların yanı sıra yeni bir akademik personelin alımı veya yükselmesi sırasında da akademisyenin geçmiş akademik faaliyetleri üzerinden değerlendirme yapılır. Öğretim üyeleri atanma ve yükselme süreçlerinde, 2547 sayılı kanun ve ÜAK ölçütlerinin yanı sıra her üniversitenin kendi ek ölçütlerine de tabidir [27]. Ancak bu ölçütler öğretim üyelerinin iş baskısı gibi mesleki sorunlar yaşamasına, yalnızca belirli dönemlerde akademik faaliyetlerde bulunulmasına, atanan personelin akademik faaliyetlerinde durgunluklar oluşmasına ve yükselme olanağ1 olan personelleri güdülemesine neden olmaktadır $[9,10,11,12]$. Tüm bu değerlendirmeler belirli ölçek sistemleri geliştirilerek sayısal puanlara dönüştürülür. $\mathrm{Bu}$ puanlar aynı zamanda bölümlerin ve fakültelerin de diğer bölüm ve fakültelere kıyasla durumunu ortaya koyar. Fakat tüm bunları yapabilmek için öncelikle her kurumun bir karar destek sistemine ihtiyacı vardır. Bu çalışmada da kurumun bu tür ihtiyaçlarını karşılayacak bir karar destek sistemi (KDS) önerisi sunulmuştur. $\mathrm{Bu}$ KDS ile yükseköğretim kurumları her an akademik faaliyet durumlarını analiz edebilecek ve değerlendirmeler yapabilecektir. Bunun yanı sıra akademik personeller de doçentlik ve akademik teşvik gibi farkı ölçüt sistemlerindeki kendi performanslarını her an görüp değerlendirebilecektir. Böylelikle değerlendirmeleri belirli dönemlere bağlamak yerine sürekli hale getirme olanağı oluşacaktır. Tüm bunların yanı sıra yükseköğretim kurumları da Türkiye'deki diğer kurumlar içerisinde kendi pozisyonunu değerlendirme imkânı bulacaktır. Ayrıca verilerin tamamının tek bir yerden 
girilmesi sonucu tüm akademik personelin özgeçmişlerinin de yayınlanması sağlanacaktır.

3. AKADEMIKK TEŞVIK ÖDENEĞİ BAŞVURU VE DEĞERLENDIRME SÜRECI (APPLICATION AND EVALUATION PROCESS OF ACADEMIC INCENTIVES)

Devlet yükseköğretim kurumları kadrolarında bulunan öğretim elemanlarına yapılacak olan akademik teşvik ödeneğinin uygulanmasına yönelik süreci her üniversite kendi içinde yürütür. Fakat Yükseköğretim Kurulu Başkanlığı Ortak Veritabanı (YÖKSİS) tarafından akademik personelin puanlarının hesaplanması gerçekleştirilerek üniversitelerin süreçteki bazı işleri kolaylaştırılmış̧ır. Başvurular üniversitelerin ilan ettiği tarihlerde YÖKSİS'ten alınan çıktı ile akademik faaliyetlere ilişkin örnek, kanıt ve belgeleri üniversitelerin ilan ettikleri usule göre Birim Akademik Teşvik Başvuru ve İnceleme Komisyonuna sunar. $\mathrm{Bu}$ komisyonun incelediği başvuruların ıslak imzalı karar tutanakları gerekli açıklamaları da içermiş haliyle Akademik Teşvik Düzenleme, Denetleme ve İtiraz Komisyonuna gönderir. Komisyon hazırladığı karar tutanağını, değerlendirme raporunu ve puan tablosunu elektronik ortamda ilan eder. Her iki komisyon da reddedilen ve puan değerinde değişiklik yapılan akademik faaliyetlere ilişkin açıklamalarını yazmak zorunda olmakla birlikte sunulan akademik faaliyetlere ilişkin isterse ek açıklama, bilgi ve belgeler talep edebilir [13].

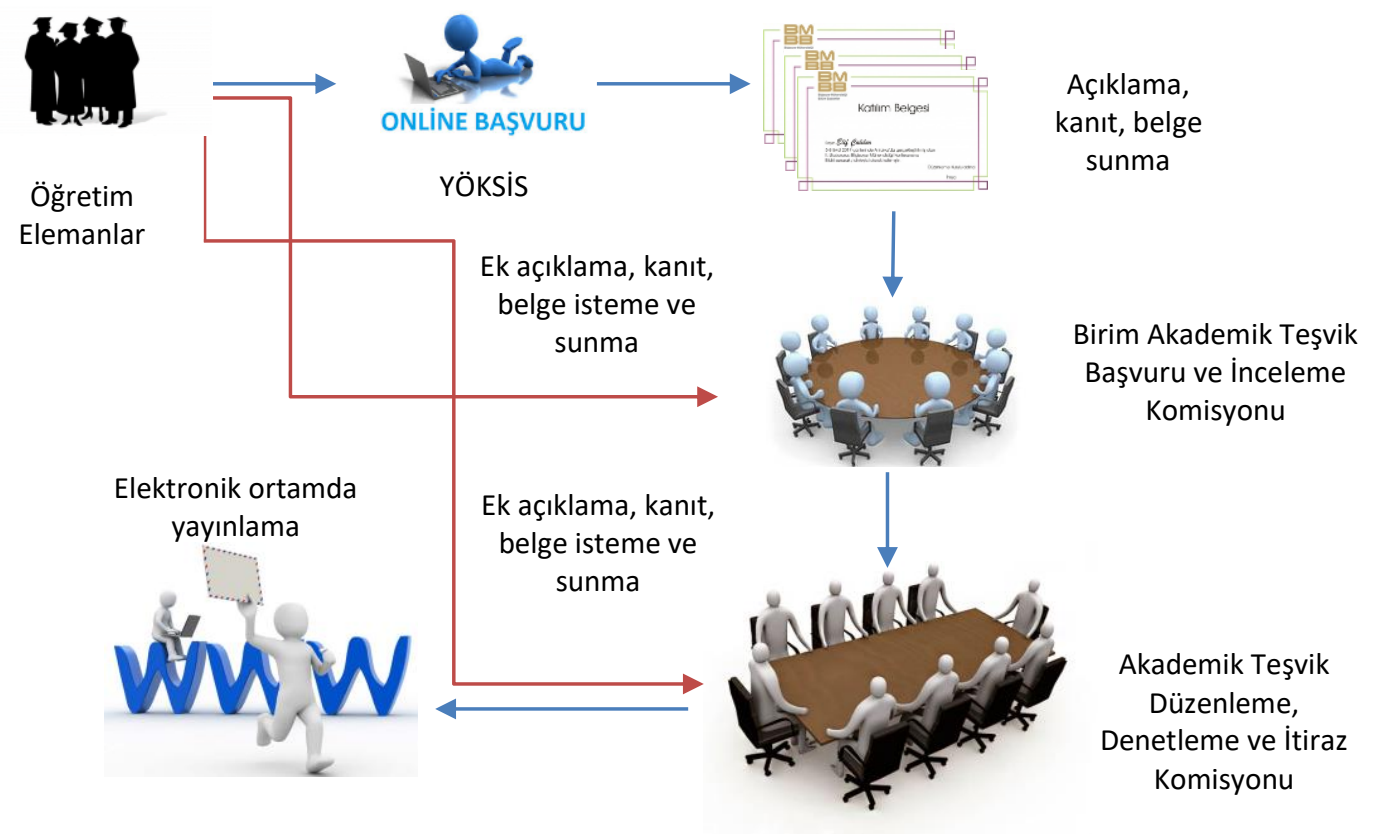

Şekil 1. Akademik Teşvik Ödeneği Başvuru ve Değerlendirme Süreci (Academic Incentive Allowance Application and Evaluation Process)

\section{DOÇENTLİK BAŞVURU VE DEĞERLENDİRME SÜRECI (APPLICATION AND EVALUATION PROCESS OF ASSOCIATE PROFESSORS)}

Doçentlik başvuruları Doçentlik Başvuru Sistemi (DBS) üzerinden tüm akademik faaliyetlerin girilmesi ve oradaki puanlamaların hesaplanması ile olur. Öncelikle başvurular ön değerlendirmeden geçer ve sonrasında Üniversitelerarası Kurul Başkanlığı (ÜAK) tarafından değerlendirme jürisi oluşturulur. $\mathrm{Bu}$ jüriler başvuru bilgileri ve akademik faaliyetleri kanıtlayıcı dokümanları ile birlikte inceler. Salt çoğunluk ile karar alınır ve kişiye doçentlik belgesi gönderilir [14]. 


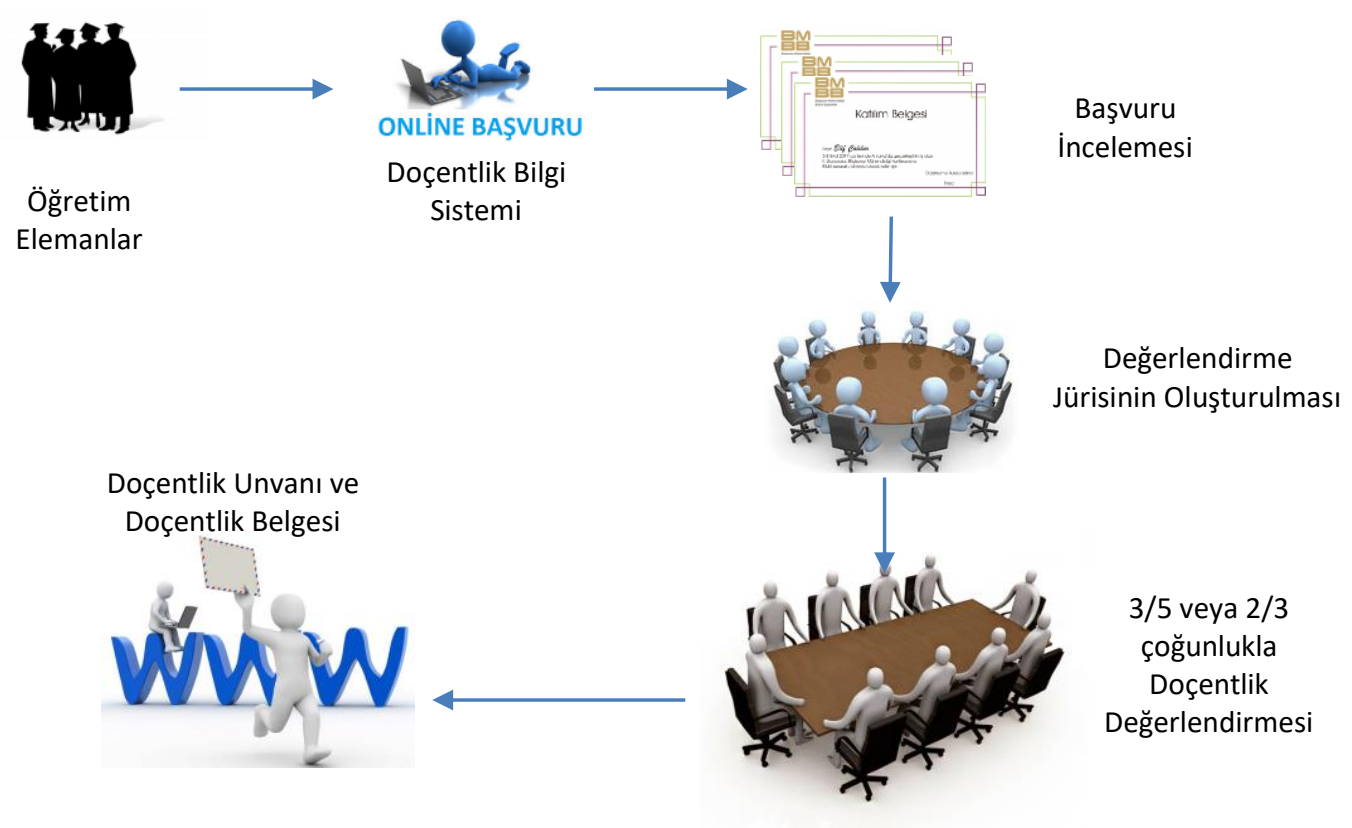

Şekil 2. Doçentlik Başvuru ve Değerlendirme Süreci (Application and Evaluation Process of Associate Professors)

\section{5. ÜNIVERSITELER AKADEMIK PERSONEL ATAMA VE YÜKSELTME SÜRECI (UNIVERSITY ACADEMIC STAFF ASSIGNMENT AND PROMOTION PROCESS)}

Her üniversite kendi akademik performansını geliştirip dünyanın en iyileri arasında yer almayı hedefler. Üniversitelerin, kendi akademik performansını diğer dünya üniversiteleriyle karşılaştırıp yeni gelişme stratejileri üretebilmeleri için bilimsel üretkenliğe dayalı ölçütler getirmesi kuşkusuz çok önemlidir [15]. Bu sebeple de her üniversitenin kendisine özgü Akademik Personel Atama ve Yükseltme Yönergesi vardır. Dolayısıyla üniversitelerin akademik faaliyetlere verdiği sayısal değerler de birbirinden farklıdır. Hatta bazı üniversiteler bir kısım akademik faaliyetlere puan verirken bazıları aynı faaliyetlere hiç puan vermemektedir. $\mathrm{Bu}$ sebeple üniversitelerin her biri için bağımsız değerlendirme yapılması gerekir.

5.1. Akademik Personel Değerlendirme Ölçütleri (Academic Staff Evaluation Criteria)

University Ranking by Academic Performance (URAP) tarafından 2018-2019 Eğitim-Öğretim yılı için açıklanan üniversite sıralamasındaki ilk beş üniversite aşağıdaki gibidir [16].

1. Hacettepe Üniversitesi (HÜ)
2. Orta Doğu Teknik Üniversitesi (ODTÜ)

3. İstanbul Üniversitesi (İ̈)

4. İstanbul Teknik Üniversitesi (İTÜ)

5. Ankara Üniversitesi (AÜ)

Örneğin ODTÜ tarafından atıflar "başka yazarlar tarafından yapılan her bir atıf" şeklinde yalnızca ulusal/uluslarası olarak ayrıştırılmış fakat onun dışında endeks veya diğer özelliklerine göre ayrıştırılmamıştır. Yine benzer şekilde ODTÜ tarafindan lisansüstü/uzmanlık tezlerinde yapılan danışmanlıkların hiçbir puan değeri yokken diğer üniversiteler arasında puan değeri vardır. Ayrıca var olanlar arasında da iç detaylarda farlılıklar görülebilmektedir. Örneğin İstanbul Üniversitesi konferans ve dergi kurullarındaki üyelikleri dikkate alırken Ankara Üniversitesi yalnızca dergi kurullarındaki üyelikleri dikkate almaktadır. Bir başka örnek olarak konferanslarda sunulan posterler kimi üniversiteler tarafindan kabul edilirken kimi üniversiteler tarafından kabul edilmemektedirler. Dikkat çeken unsurlardan bir tanesi de diğer üniversiteler tarafindan dikkate alınan patentlerin Hacettepe Üniversitesi tarafindan dikkate alınmıyor olmasıdır Bazı üniversitelerin teknik alanlara odaklanması nedeniyle sanatsal etkinlikleri dikkate almadığı da bilinmektedir. Yukarıda belirtilen beş üniversitenin ölçütleri incelenerek oluşturulan karşılaştırmalı bilgiler Tablo 5'te verilmektedir [17]. 
Tablo 1. URAP Sıralamasındaki İlk Beş Üniversitenin Akademik Performans Ölçütleri (Academic Performance Measures of the First Five Universities in the URAP Ranking)

\begin{tabular}{|c|c|c|c|c|c|}
\hline Ölçüt & $:$ & อి & :ַ & : & : \\
\hline Ulusal/ Uluslararası Dergide Makale & + & + & + & + & + \\
\hline $\begin{array}{l}\text { Ulusal/ Uluslararası Editöre Mektup, Teknik Not, Vaka İncelemesi, Tartışma, Kitap } \\
\text { İncelemesi }\end{array}$ & + & + & + & - & - \\
\hline Ulusal/ Uluslararası Kitapta Bölüm & + & + & + & + & + \\
\hline Ulusal/ Uluslararası Kitap & + & + & + & + & + \\
\hline Ulusal/ Uluslararası Editörlük & + & + & + & + & + \\
\hline Ulusal/ Uluslararası Konferans Bildirisi & + & + & + & + & + \\
\hline Ulusal/ Uluslararası Konferans Sunumu & - & + & + & - & + \\
\hline Ulusal/ Uluslararası Kitap Çevirisi & + & + & + & + & + \\
\hline Ulusal/ Uluslararası Makale/Bölüm Çevirisi & + & + & + & + & + \\
\hline Ulusal/ Uluslararası Atıflar & + & + & + & + & + \\
\hline Ulusal/ Uluslararası Çalışma İncelemesi & - & + & - & - & - \\
\hline Ulusal/ Uluslararası Proje Yarışması & - & + & - & + & - \\
\hline Ulusal/ Uluslararası Ödül & - & + & + & + & + \\
\hline Ulusal/ Uluslararası Gerçekleştirilmiş Projeler Üzerine Yayınlar & - & + & - & - & - \\
\hline Ulusal/ Uluslararası Gerçekleştirilmiş Fikir Projesi Üzerine Yayınlar & - & + & - & - & - \\
\hline Uluslararas1 Patent & - & + & + & + & + \\
\hline Uluslararası Proje & + & + & + & + & + \\
\hline Ulusal Proje & + & - & + & + & + \\
\hline Uluslararası Bilirkişi Raporu & - & + & - & - & - \\
\hline Bilimsel-Sanatsal Etkinlikler & + & - & + & - & + \\
\hline h İndeksi / Etki Faktörü & - & - & - & + & - \\
\hline Lisansüstü veya Uzmanlık Tezlerinde Danışmanlık & + & - & + & + & + \\
\hline Hakemlik & - & - & + & + & + \\
\hline Kurul Üyelikleri (Dergi, Konferans vb.) & - & - & + & + & + \\
\hline Makale Keşfi (Short Communication) & + & - & - & - & - \\
\hline Eğitim-Öğretim Etkinliği (Ders Verme) & - & - & - & + & + \\
\hline Sertifikalar (Öğrenen/Öğreten) & - & - & + & - & + \\
\hline İdari Görevler & - & - & - & + & + \\
\hline Diğer Konularda Görev Almak & - & - & - & + & + \\
\hline
\end{tabular}

Burada incelenen üniversitelerden bazılarının puanları sağlık, fen, sosyal ve mühendislik gibi farklı kategorilere ayırdığı görülmüştür. Bu kategorilerden bazılarını fenmühendislik-sağlık şeklinde birleştirerek uygulayanlar olduğu gibi bir başka alana özgü ölçütleri ve ayrı puanları olan yönergeye sahip üniversiteler de vardır.

\section{YÜKSEKÖĞRETIMM BİLGİ SİSTEMİ (HIGHER EDUCATION INFORMATION SYSTEM)}

Yükseköğretim Kurulu tarafindan geliştirilen bu sistem Türkiye'deki tüm yükseköğretim kurumlarındaki verileri tek bir havuzda toplayıp istatistiki veri elde etmeyi amaçlamaktadır. Bu sistem üzerinden akademik teşvik puanları hesaplaması da yapılmaktadır [28]. Fakat bu sistemi bir KDS olarak görmek pek doğru olmayacaktır. Burada tüm akademik personelin faaliyetlerinin girişi istenmektedir fakat zorunlu tutulamamaktadır. Yalnızca en son akademik teşvik puanlama ölçütüne göre hesaplama yapılabilmekte ve kişisel raporlar elde edilebilmektedir [29]. Bu sistemin amaçları arasında yükseköğretim kurumlarının ihtiyaçları karşılamak yoktur.

\section{KARAR DESTEK SISTEMI (DECISION SUPPORT SYSTEM)}

Karar destek sistemleri (KDS) karar süreci içerisindeki herhangi bir anda karar veren kişinin işini kolaylaştırmak amacıyla, özellikle alternatiflerin geliştirilmesi ve bu karar alternatiflerinin değerlendirilmesi için gerekli bilgilerin toplanması ve analizi için oluşturulan bilgisayar temelli sistemlere denir [30]. Burada temel amaç, karar veren kişiye daha iyi denetim olanağı tanımak ve bu kişilerin karar süreçlerine yön verecek bilgi ve analitik destek sağlamaktır. KDS'lerde uzman sistemler gibi insan mantığını taklit ederek ve problemleri bir uzman kişi gibi çözmeye çalışarak karar oluşturma mekanizması yoktur. Yani KDS soruna belirli bir cevap veya çözüm sağlama amacı taşımaz. Bunun yerine karar veren kişilere yararlı bilgi sunmak ve analiz sürecinde karar veren kişinin mevcut yeteneklerine destek olacak kullanımı kolay 
araçlar sağlamak amaçlanır. Böylelikle karar vericinin bilgi hatırlama ve muhakeme işlemlerini daha etkin ve daha verimli hale getirmek de hedeflenir. Sonuçta karar vericiler veri düzenleme işi ile uğraşarak zaman kaybı yaşamamakta, örgütün mevcut durumunu daha iyi görme, alternatif senaryoları ve en fazla ümit vadeden eylemi inceleyerek karar verme olanağına kavuşmaktadır [18]. Özellikle eğitim kurumlarında teknolojinin kullanımına yapılan yatırımların bu tür KDS'ler ile daha etkin ve verimli kullanılacağı düşünülmektedir [31, 32]. Böylece operasyonların ve hizmetlerin kalitesi yükselecek olup verimlilik, şeffaflık ve hızlı karar alma olanağı oluşacaktır [33].

\section{AKADEMIK PERSONEL PERFORMANS DEĞERLENDİRME KARAR DESTEK SİSTEMI (ACADEMIC STAFF PERFORMANCE EVALUATION DECISION SUPPORT SYSTEM)}

Yükseköğretim kurumu tarafindan geliştirilen ve hem akademik teşvik hem de doçentlik için kullanılan sistem incelenmiştir. Ayrıca yükseköğretim kurumlarından beş tanesinin atanma ve yükseltme yönergesindeki ölçütler incelenerek harmanlanmış ve karar destek sistemine eklenmiştir. KDS için oluşturulan sistemin ekran görüntüleri de örnek olarak sunulmuştur.

\subsection{Veri Girişleri (Data Inputs)}

Bir kısım üniversiteler kendi akademik faaliyetlerini raporlamak amacıyla dışarıdan hizmet alımı ile çeşitli yazılımlar kullanmaktadır. Fakat bunların sayısı ancak 22 civarında kalmıştır. Bu yazılımlar kişisel web sayfaları sunulması, anlık veya dönemsel faaliyet raporları ve istatistiksel bilgilerin üretilmesi gibi muhtelif amaçlara yöneliktir [19]. Buradaki çalışma da kısmen benzerlik gösterse dahi birçok farklılıkları bulunmaktadır. Aşağıdaki şekilde örnek olması açısından makale girişi gösterilmiştir.

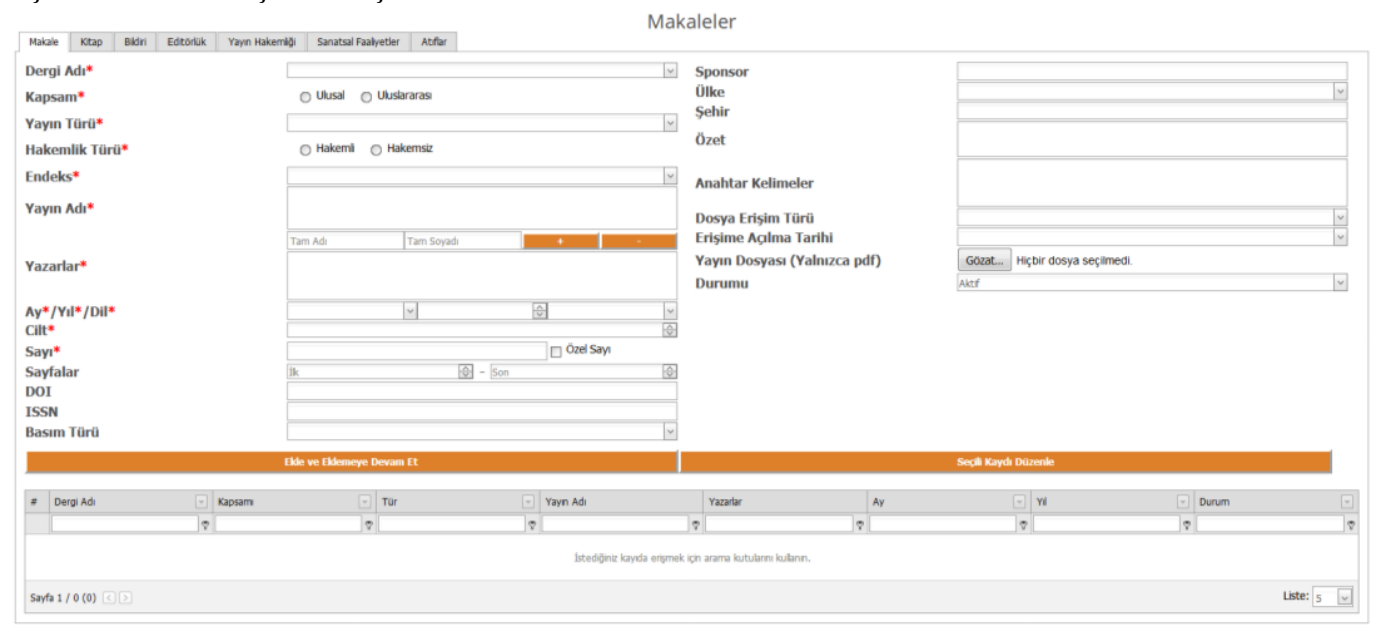

Şekil 3. Örnek Akademik Faaliyet Girişleri (Sample Academic Activity Entries)

Şekil 3'te verilen örnek bilgi giriş ekranı incelendiğinde, bir akademik faaliyete ilişkin birçok detay bilgi istendiği görülecektir. Bunun nedeni birden fazla parametreye göre akademik faaliyet puanlarının hesaplanmasında ilgili alanlara ihtiyaç duyulmasıdır. Ayrıca buradaki tüm açılır listelerdeki veriler parametrik olup kullanıcı tarafindan değiştirilebilen yapıdadır. Bilgi girişi istenen akademik faaliyetlerin temel başlıkları aşağıdaki gibidir. Her başlığın iç detayları çok uzun olması nedeniyle burada verilememiştir.

$\begin{array}{ll}\text { - } & \text { Makaleler } \\ \text { - } & \text { Kitaplar } \\ \text { - } & \text { Bildiriler } \\ \text { - } & \text { Editörlükler } \\ \text { - } & \text { Sakemlikler } \\ \text { - } & \text { Atıflar } \\ \text { - } & \text { Projeler } \\ \text { - } & \text { Ödüller } \\ \text { - } & \text { Patentler } \\ \text { - } & \text { Jürilikler }\end{array}$

- $\quad$ Lisans ve Lisansüstü Tez Danışmanlıkları

- Dersler

- Diğer Bilimsel Etkinlikler

- Belgeler/Sertifikalar

- Eğitim Geçmişi

- Uzmanlık Alanları

- İs Deneyimleri ve Süreleri

- Üyelikler

- Alinan Unvanlar

Ekranlar aracılığıyla akademik faaliyetler kayıt altına alındıktan sonra her kurumun kendi ölçütlerine göre yapılandırılan hesaplamalar sonucu her bir akademisyen için akademik performans puanları ortaya çıkmaktadır. Yetki verilen yöneticiler kendi birimlerine ait personellerin genel performans puanını görebildiği gibi, bu puanların ortaya çıkaran detay faaliyetlere ve bu faaliyetlerin tüm ayrıntılı bilgileri ile birlikte kanıtlayıcı dokümanlarına da ulaşabilmektedir. Şekil 4'te akademik personellerin performans puanlarının izlenme ekranı gösterilmiştir. 


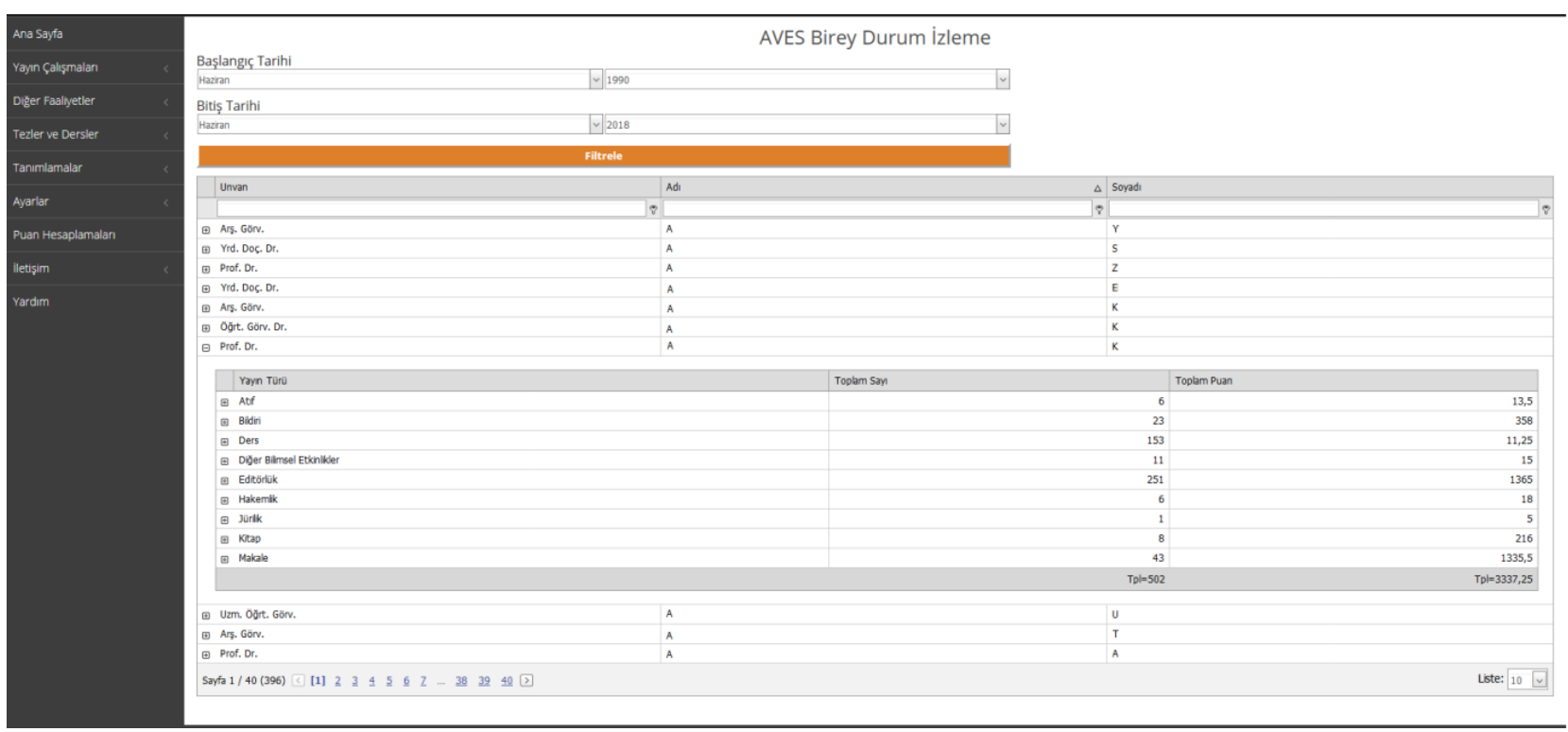

Şekil 4. Akademik Personel Faaliyet Performans Puanları İzleme Ekranı (Academic Staff Activity Performance Score Monitoring Screen)

\subsection{Değerlendirme Süreci (Evaluation process)}

Elbette akademik personelin tüm faaliyetlerini yazması sonucu gerçek puanın oluşması bazı durumlarda yanıltıcı olabilmektedir. Örneğin öğretim elemanının bir bildiriyi sisteme kaydederken sehven ulusal yerine uluslararası seçeneğini seçmesi veya kurumun ölçütleri açısından uluslararası sayılmaması gibi durumlar neticesinde yanıltıcı puanlar ortaya çıkmaktadır. Bu durumu önlemek için ise her bir akademik faaliyetin girişi sonrası kurum tarafindan atanan ve sistemde yetkilendirilen kontrolörler bu faaliyete ilişkin tüm detayları inceleyip, kurum ölçütleri açısından kabul edilebilir olup olmadığını sisteme işlemektedir. Uygun görülmeyen faaliyetler pasife çekilip performans puanlarının hesaplamasında dikkate alınmamakta ve yazarına bilgi giderek düzenleme veya kanıtlayıcı doküman yüklemesi istenmektedir. İkinci bir değerlendirme sonrası faaliyetin puanı yansıtılabilir. Şekil 5 'te bu süreç görsel olarak verilmiştir.

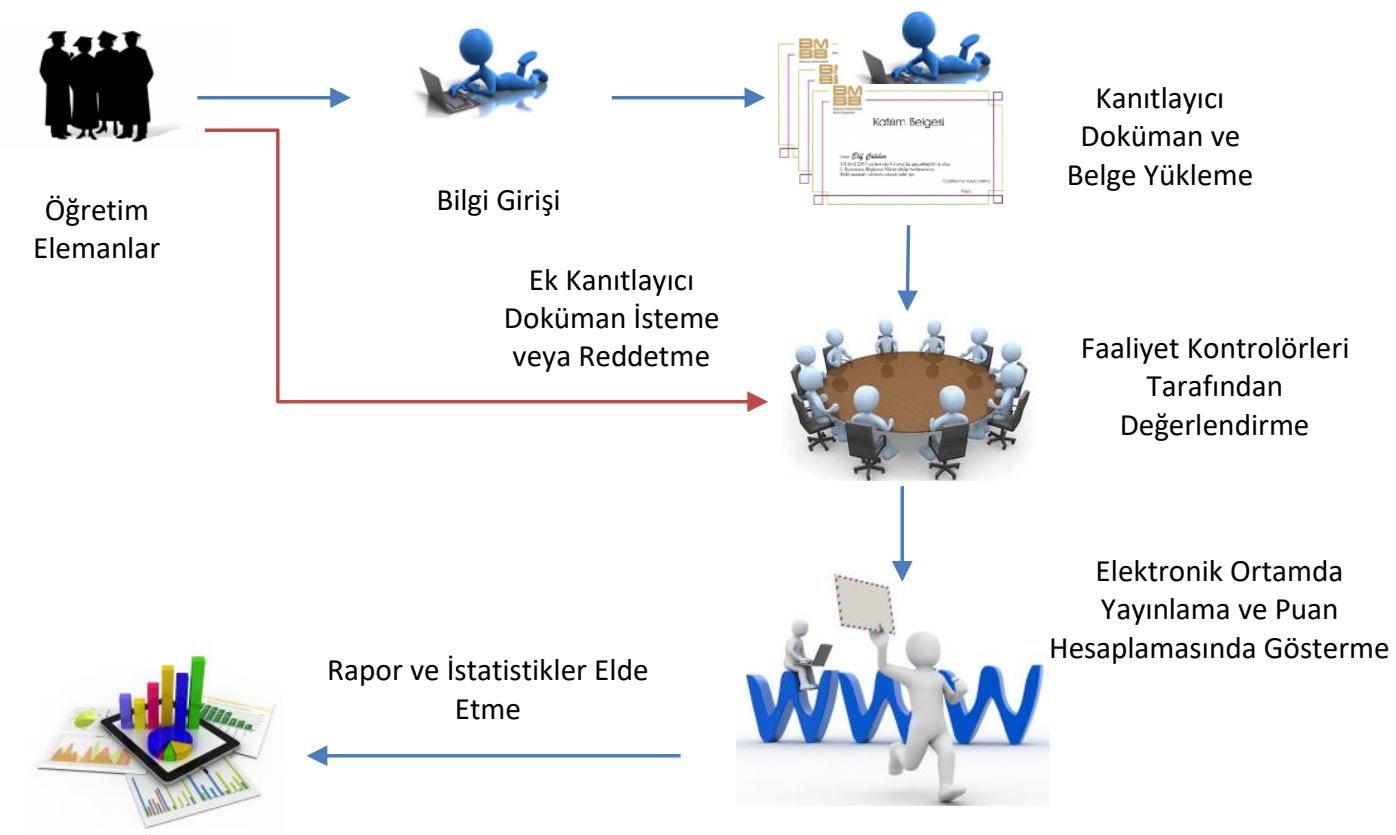

Şekil 5. Akademik Personel Faaliyet Giriş Süreci (Academic Staff Activity Introduction Process) 


\subsection{Hesaplama Parametreleri Girişi (Calculation Parameters Input)}

Akademik faaliyet grupları daha önceki başlıklarda bahsedilmişti. Bu grupların her birinde puanlamaya esas olan belirli alt başlıklar vardır. Bu alt başlıkların çok sayıda olması nedeniyle temel birkaç alan için örnek olarak aşağıdaki Tablo 2'de verilmiştir.

Tablo 2. Puanlama Alt Bașlıkları (Rating Subtitles)

\begin{tabular}{|c|c|c|c|}
\hline Makale & Bildiri & Proje & Atif \\
\hline $\begin{array}{l}\text { - Kapsam (Ulusal, } \\
\text { Uluslarası) } \\
\text { - Tür (Makale, Editöre } \\
\text { Mektup, Çeviri } \\
\text { Makale...) } \\
\text { - Hakemlik Durumu } \\
\text { (Hakemli, Hakemsiz) } \\
\text { - Endeks (SCI, SSCI, } \\
\text { AHCI, Ulakbim...) } \\
\text { - Yazar Sayısı } \\
\text { - Yazar Sirası }\end{array}$ & $\begin{array}{l}\text { - Kapsam (Ulusal, } \\
\text { Uluslarası) } \\
\text { - Tür (Özet, Tam Metin, } \\
\text { Poster...) } \\
\text { - Hakemlik Durumu } \\
\text { (Hakemli, Hakemsiz) } \\
\text { - Endeks (SCI, SSCI, } \\
\text { AHCI, Ulakbim...) } \\
\text { - Yazar Sayısı } \\
\text { - Yazar Sirası }\end{array}$ & $\begin{array}{l}\text { - Kapsam (Ulusal, } \\
\text { Uluslarası) } \\
\text { - Tür (AB, BAP, } \\
\text { Tubitak, İSTKA...) } \\
\text { - Araştırma Kapsamı } \\
\text { (ARGE, Üniversite- } \\
\text { Sanayi İşbirliği, } \\
\text { Diğer...) } \\
\text { - Görev (Yürütücü, } \\
\text { Araştırmacı, } \\
\text { Danışman...) } \\
\text { - Yazar Katkı Oranı }\end{array}$ & $\begin{array}{l}\text { - Atıf Yapılan Çalışmanın } \\
\text { Türü (Makale, Bildiri, } \\
\text { Kitap...) } \\
\text { - Tür (Makale, Editöre } \\
\text { Mektup, Çeviri Makale...) } \\
\text { - Kapsam (Ulusal, } \\
\text { Uluslarası) } \\
\text { - Hakemlik Durumu } \\
\text { (Hakemli, Hakemsiz) } \\
\text { - Endeks (SCI, SSCI, } \\
\text { AHCI, Ulakbim...) }\end{array}$ \\
\hline
\end{tabular}

Puanlama işlemi her kurumun kendisine özel olması nedeniyle yukarıdaki Tablo 2'de örnek olarak gösterildiği gibi alt başlıklar üzerinden parametrik olarak puan değerlerinin girişini istemektedir. Her yükseköğretim kurumu kendi atama yükseltme yönergesi doğrultusunda bu parametre değerlerini doldurarak puanların oluşmasını sağlar. Bunların dışında da birçok detay bilgi puanlama ölçütleri içerisinde yer almasa da (örneğin bildiri adı, makale adı, sayfa numaraları vb.) zorunlu olarak istenmektedir. Hesaplama parametrelerinin nasil girildiğini gösteren örnek bir ekran Şekil 7'de gösterilmiștir.

\section{Makale Değerlendirme Puanları}

\begin{tabular}{l|l|l|} 
Kapsam* & O Ulusal O Uluslararası \\
Yayın Türü* & & \\
Hakemlik Türü* & & \\
Endeks* & & \\
Puan* & & \\
\hline
\end{tabular}

Şekil 7. Hesaplama Parametrelerinin Girişi (Input of Calculation Parameters)

Her bir faaliyet grubu için benzer şekilde kendisine has özellikleri dikkate alarak hesaplama parametreleri girilir. Puan hesaplamalarında ise buradaki değerler dikkate alınır. Böylelikle her kurum kendi atama ve yükseltme yönergesinde yer alan puanını görebilecektir.

\section{3. Özgeçmiş Sayfası (CV Page)}

Tüm akademik faaliyet verileri sistemde kayıtlı olması nedeniyle her kurumun istediği kaynak gösterim formatına uygun bir şekilde veriler gösterilerek akademik personel web sayfaları oluşturulabilir. $\mathrm{Bu}$ web sayfalarının tasarımı her kurumun kendisine özgü olarak tasarlanabilir. Çalıșma kapsamında oluşturulan örnek bir akademik personel web sayfası aşağıdaki Şekil 6'da gösterilmiştir. 


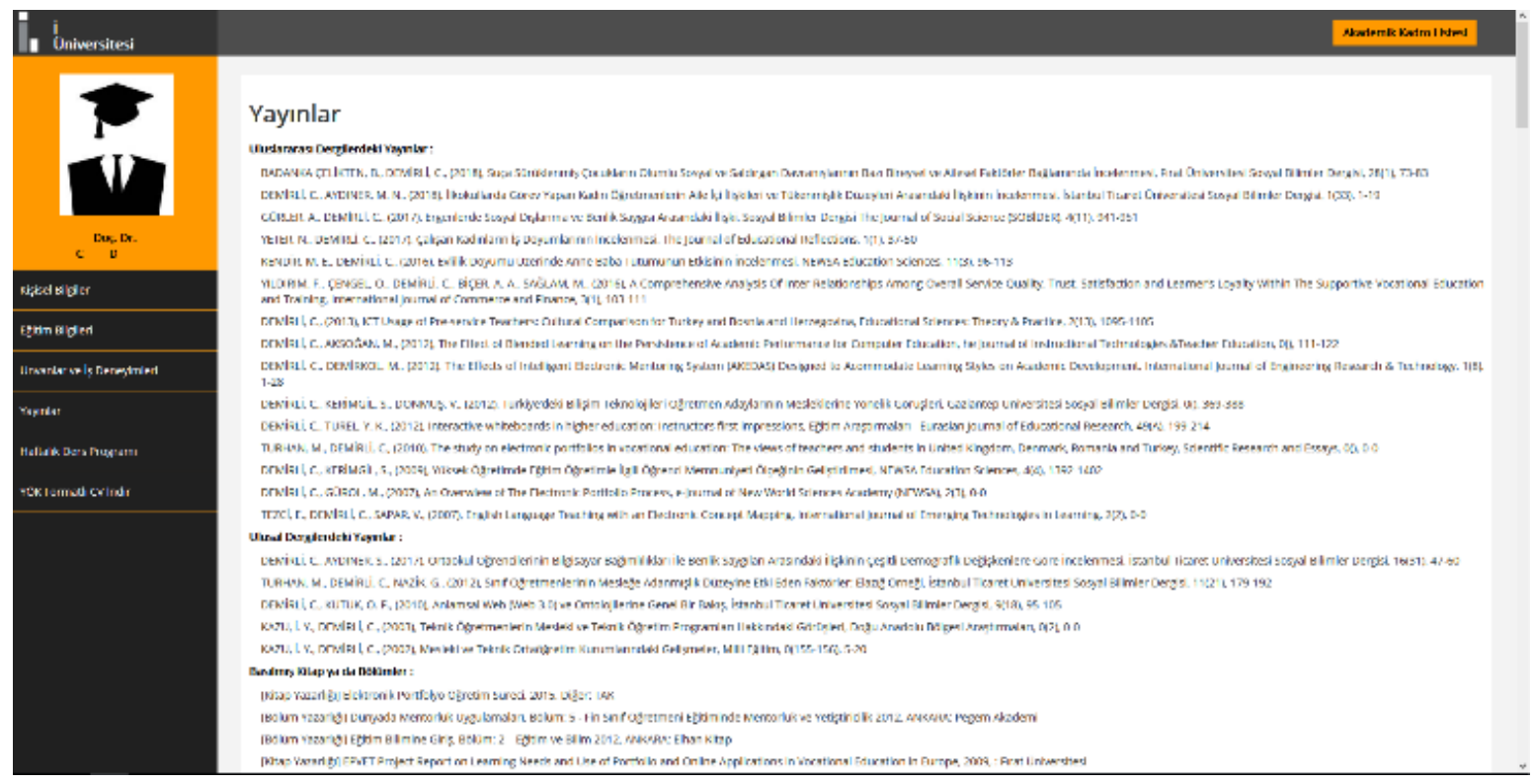

Şekil 6. Akademik Personel Özgeçmiş Sayfası (Academic Staff CV Page)

\section{TARTIŞMA VE SONUÇ (DISCUSSION AND CONCLUSION)}

Yapılan herhangi bir değerlendirmenin öznellikten uzaklaşması ve daha çok nesnel duruma kavuşması için her şey önce bir sayısal değere endekslenmeye çalışılır. Böylece, yapılan değerlendirme sonucunda herhangi bir kuşkuya yer bırakmayacak şekilde ve nesnel olarak ölçme gerçekleştirildiği düşünülür. Fakat bu durumun her zaman için doğru olduğu söylenemez. Bazı durumlarda bu somut veriler yanıltıcı olabilir. Örneğin bir akademik personel alım karar sürecinde kurumların çoğunluğu öncelikle geçmiş akademik puanlarını değerlendirmeye tabi tutar. $\mathrm{Bu}$ değerlendirmede her şey sayısal bir değere çevrilir. Fakat buradaki faaliyet sahibinin kurumun ölçütlerine uyduğunu iddia ettiği tüm faaliyetler bir başka kişi tarafından incelenmeli ve değerlendirilmelidir. Ancak o zaman buradaki sayısal değerler bir gerçeği yansıtabilir. Fakat buradaki değerlendirmede doçentlik değerlendirmelerinde olduğu gibi akademik personelin özgeçmişini, yayın sayısı ve türlerini değerlendirmek değildir [20]. Tam tersi olarak her bir yayının ilgili ölçek kriterleri ile uyuşup uyuşmadığının kontrolüdür. Ayrıca her tür akademik faaliyetin değerlendirilmesi önemlidir. Örneğin bir konferansta özet veya tam metin bildiri sunmak bir akademik personel için sayısal değeri olan bir faaliyet iken o konferansı düzenleyen kişi olmak bir faaliyet değilse bu durum yanıltıcı olabilir veya dar kapsamlı bir ölçme yapılmış olabilir. Akademik personelin performanslarının değerlendirilmesinde özellikle h dizini veya yalnızca dergi etki faktörü gibi k1sıtlı ölçütler üzerinden değerlendirmeler yapmak, bireylerin öğretim elemanı olmasında ve yükselmesinde hem yaşamını hem de kariyerlerini etkileyen bazı yanlış ve eksik ölçümlere sebep olabilir. Bu durum öğretim elemanları görüşlerinde de kaygı verici bir durum ve sorun olarak ifade edilmiştir [21]. Türkiye'deki yükseköğretim kurumlarının değerlendirilmesindeki güçlükler arasında onların karmaşık yapıları ve verimlilik ile performans ölçmedeki zorluklar yer alır. Bu durum eğitim-öğretim, bilimsel araştırma ve toplumsal kalkınma amaçlarından hangisini önceleyeceği konusunda önemli zorluklar oluşturmaktadır [22]. Yükseköğretim kurumları kendi bilimsel faaliyetlerini değerlendirirken kurum için kuşkusuz en önemli unsur atama ve yükseltme yönergeleridir. Fakat kurumsallaşma düzeyi farklı olan üniversitelerin her birinin kendi atama ve yükseltme ölçütlerine yönelik tek bir formül veya bağlantı geliştirilememektedir. Aynı endekste bulunan bir dergideki çalışma için üniversiteler farklı puanlar verebilmektedir. $\mathrm{Bu}$ durum her üniversitenin benzer akademik faaliyetlere farklı derecede önem verdiğini göstermektedir [23].

Bu çalışmada üniversitelerin kendisine özgü olan atama ve yükseltme yönergelerindeki ölçütlere göre akademik personel performans puanları hesaplanabilecektir. Hesaplanan puanlar bir kontrolör tarafindan incelenip onaylandıktan sonra akademik personel, bölüm, fakülte ve hatta üniversite sıralamalarında kullanılabilecektir. Fakat her ne kadar öğrenci ödevi niteliğini aşmayan yazıların hakemli dergilerde makale olarak yayınlandığı [24] kontrolörler tarafindan görülse dahi; bu tür konular çalışma kapsamında değerlendirme dışı bırakılmış ve puanlaması yok kabul edilmiştir. Değerlendirmede süreklilik durumu değerlendirmenin belirli dönemlere indirgenmesini ortadan kaldıracaktır. Buradaki sistem her bir üniversite için ayrı ayrı kullanılabileceği gibi YÖK gibi çatı bir kurum tarafindan kullanıma açılırsa her bir akademik personel hem kendi üniversitesindeki puanını hem de Türkiye geneli puanını görebilmesi sağlanacaktır. Buradaki puanlar akademisyenleri nicel olarak akademik faaliyetlerini değerlendirmek ile sınırlıdır fakat bilimi matematiksel olarak değil de kazandırılan nitelikler olarak değerlendirecek ölçütlerin varlığı önemlidir [25]. Bu ölçütlerin de dikkate alınmasıyla hem nicelik hem de nitelik birlikte dikkate alınacaktır [26]. Nihayetinde bir öğretim üyesinin bir kısım çalışmalarının dikkate 
alınmaması onun nicel olarak eksik değerlendirilmesi dolayısıyla niteliksel tespitin de zayıf olacağı muhakkaktır. $\mathrm{Bu}$ çalışma kapsamında önerilen değerlendirme sisteminde bu tür ölçütlere azami dikkat edilerek bir akademisyeni bütün olarak değerlendirmek amaçlanmıştır. İleride yapılacak farklı çalışmalar ile bir akademik personelin öğrenciler, kurum amirleri ve meslektaşları tarafından değerlendirilmesinin de performans değerlendirmesine farklı açılardan bakılması için yararlı olacaktır.

\section{KAYNAKLAR (REFERENCES)}

[1] A. Yağmurlu, S. Baskan, Akademik yükseltme ve atamalarda ulusal süreli yayınlarımız, Sağlık Bilimlerinde Süreli Yayıncılık, Ankara, 2005.

[2] U. Al, İ. Soydal, "Akademinin atıf dizinleri ile savaşı", Hacettepe Üniversitesi Edebiyat Fakültesi Dergisi, 31(1), 23-42, 2014.

[3] M. A. Tekinsoy, M. B. Misır, "Öğretim Üyeliğine Atanma Sürecinin Başlangıcı, Ek Koşullar ve Jüri Raporları”, AUHFD 61(1), 351-382, 2012.

[4] İ. Turan, "Kalite Sorununu Aşmada Atama ve Yükseltme Kriterleri”, Uluslararası İlişkiler Dergisi, 4(13), 129-136, 2007.

[5] C. İpek, E. Gök, “ABD ve Türkiye Yükseköğretim Sisteminde Akademik Personelin İstihdamı, Terfi Uygulamaları Ve Türkiye Yükseköğretim Sistemi İçin Bazı Öneriler”, TYB Akademi Dil Edebiyat ve Sosyal Bilimler Dergisi, 5 (1), 177-200, 2015.

[6] M. Esen, D. Esen, “Öğretim Üyelerinin Performans Değerlendirme Sistemine Yönelik Tutumlarının Araştırılması”, Yükseköğretim ve Bilim Dergisi, 5(1), 52-67, 2015.

[7] Y. Tonta, “Türkiye'de Yayımlanan ve Web of Science'ta Dizinlenen Dergilerle İlgili Bir Değerlendirme", Türk Kütüphaneciliği, 31(4), 449-482, 2017.

[8] T. Karataş, Ş. Özen, E. Gülnar, "Akademisyenlerin Kariyer Basamakları ve Yükseltme Ölçütlerine İlişkin Görüşleri”, Yükseköğretim Dergisi, 7 (2), 82-93, 2017.

[9] D. Esen, Öğretim üyelerinin performans değerlendirme sistemine yönelik tutumlarının belirlenmesi üzerine bir araştırma. Yüksek Lisans Tezi. Kocaeli Üniversitesi, Kocaeli, 2011.

[10] M. Tuzgöl Dost, F. Cenkseven, "Devlet ve vakıf üniversitelerinde çalışan öğretim elemanlarının mesleki sorunları”, Çukurova Üniversitesi Sosyal Bilimler Enstitüsü Dergisi, 16(2), 203-218, 2007.

[11] K. Demir, "Ankara üniversitesi eğitim bilimleri fakültesi araştırma görevlilerini güdüleyen özendirme araçları", Ankara Üniversitesi Eğitim Bilimleri Fakültesi Dergisi, 32(1), 277-293, 1999.

[12] A. H. Winefield, C. Boyd, J. Saebel, S. Pignata, Job stress in university staff: An Australian research study, Bowen Hills Qld: Australian Academic Press, 2008.

[13] Internet: Akademik Teşvik Ödeneği Yönetmeliği, Resmi Gazete (Sayı: 30461). http://www.mevzuat.gov.tr, 15.04.2018.

[14] Internet: Doçentlik Yönetmeliği. (2018, 15 Nisan). Resmi Gazete
(Sayı: 30392), http://www.resmigazete.gov.tr, 15.04.2018.

[15] N. Konan, S. Yılmaz, "Üniversitelerin Sıralanma Ölçütleri ve Türkiye Üniversiteleri için Öneriler”, Yüksekögrretim ve Bilim Dergisi, 7(2), 200-210, 2017

[16] Internet: URAP, 2018-2019 - TABLO 8: Tüm Üniversitelerin Genel Puan Tablosu. http://tr.urapcenter.org, 25.10.2018.

[17] Internet: YÖK, Atanma Kriterleri, www.yok.gov.tr, 27.10.2018.

[18] S. Üreten, Üretim/işlemler yönetimi: stratejik kararlar ve karar modelleri, Gazi Kitabevi, 2004.

[19] Internet: ABIS, Abis Yazılım ve Teknoloji, http://www.abisteknoloji.-com.tr, 19.07.2018.

[20] Internet: Y. Tonta, Akademik performans, öğretim üyeliğine yükseltme ve yayın destekleme ölçütleriyle ilgili bir değerlendirme, http://yunus.hacettepe.edu.tr, 01.08.2018

[21] E. Demir, C. Göloğlu Demir, M. Ç. Özdemir, "Akademik Yükseltme ve Atama Sürecine Yönelik Öğretim Üyesi Görüşleri”, Yükseköğretim ve Bilim Dergisi, 7(1), 12-23, 2017.

[22] M. C. Suchman, "Managing legitimacy: Strategic and institutional approaches", Academy of Management Review, 20(3), 571-610, 1995.

[23] Y. Alpaydın, G. Türkmenoğlu, “Türk Üniversitelerinde Öğretim Üyeliğine Yükseltme ve Atama Kriterlerinin İncelenmesi”, Marmara Üniversitesi Atatürk Eğitim Fakültesi Eğitim Bilimleri Dergisi, 47(47), 1-22, 2017.

[24] R. Okçabol, “Türkiye'de Üniversitelerin Temel Sorunları", Toplum ve Demokrasi Dergisi, 8(17-18), 23-49, 2015.

[25] T. Karataş, Ş. Özen, E. Gülnar, "Akademisyenlerin Kariyer Basamakları ve Yükseltme Ölçütlerine İlişkin Görüşleri”, Journal of Higher Education/Yüksekögretim Dergisi, 7(2), 82-93, 2017.

[26] O. İnci, Bilimsel Yayın Etiği İlkeleri, Yanıltmalar Yanıltmaları Önlemeye Yönelik Öneriler. Sağlık Bilimlerinde Süreli Yayıncılık, Ankara, 2009.

[27] Yükseköğretim Kanunu, T. C. Resmî Gazete, 17506, 4 Kasım 1981.

[28] Internet: YÖKSİS, Yükseköğretim Bilgi Yönetim Sistemi, https://yoksis .yok.gov.tr, 30.03.2019.

[29] A. Bobat, E. Çakılcı, S. Yılmaz, "Akademik Teşvikte Güncel Tartışmalar", Current Debates in Public Finance \& Public Administration: Current Debates in Social Sciences Series, 27(12), 153-167, 2018

[30] H. Gökçen, Yönetim Bilgi Sistemleri, Palme Yayıncılık, Ankara, 2007.

[31] A. Topuz, Y. Göktaş, "Türk eğitim sisteminde teknolojinin etkin kullanımı için yapılan projeler: 1984-2013 dönemi”. Bilişim Teknolojileri Dergisi, 8(2), 99-110, 2015.

[32] M. Damar, E. Coşkun, "Üniversitelerde Bilgi İşlemden Yönetim Bilişim Sistemlerine Geçiş: Mevcut Durum ve Beklentiler", Bilişim Teknolojileri Dergisi, 10(1), 21-31, 2017.

[33] İ. H. Bilgen, "Yönetim Bilgi Sistemi Tasarımında Stratejik Plana Dayalı Bilgi Katmanları Modeli”, Bilişim Teknolojileri Dergisi, 12(1), 9-22, 2019. 